\title{
Simon Springer: Fuck Neoliberalism: Translating Resistance
}

\author{
PM Press, Oakland, CA, 2021, 240 pp, ISBN: 978-1-62963-789-1 (PB), \\ 978-1-62963-813-3 (ebook)
}

\section{Kenneth Sebastián León ${ }^{1}$ (D)}

Published online: 15 May 2021

(c) The Author(s), under exclusive licence to Springer Nature B.V. 2021

Academia can be stifling. For first-generation scholars and persons from historically excluded and marginalized backgrounds, in particular, the doctoral degree can feel like a practice in cognitive dissonance. In Fuck Neoliberalism: Translating Resistance, Simon Springer cuts loose and offers a succinct and personalized interpretation of neoliberalism and its corresponding harms to our increasingly globalized world.

When I say that the argument is succinct, I mean that it is captured in a total of eight pages. If you have read the title, then you have understood the core of the argument: fuck neoliberalism!

In addition to the core thesis, the title of the book also contains the translocal ethos and original contribution of translating resistance. In physical form (more about e-books later), this book was made to travel. The structure of the text is presented in twenty-one chapters, each of which serves as a translation of the original eight-page essay. Each chapter begins with a brief introduction (in English) by the translator, sharing context, motivation, and the personal relationship that the translator has with both the original essay and the experience of translating it to another language.

The writing style is accessible, candid, and with lots of heart. I do not know the author, but Springer introduces parts of himself in both intended and unintended ways. For instance, I learned about the author's motivations (and traumatic experiences) in navigating respectability politics in academia. One has to be somewhat of an insider to appreciate the cathartic "fuck you!" that the author delivers effectively to a former supervisor. This may not resonate with all readers because not everyone will be familiar with the uglier features (or structural issues) of working in academia, and experiences will vary across diverse kinds of people.

Springer notes how it "is potentially quite dangerous to simply stick our heads in the sand and collectively ignore a phenomenon that has had such devastating and debilitating effects on our shared world" (p.11). In my own work, I have characterized major portions of what we do (in criminology conferences, specifically) as analogous to rearranging chairs on the Titanic. As such, I concur wholeheartedly with Springer's frustrations that we are

Kenneth Sebastián León

Kenneth.sebastian.leon@rutgers.edu

1 Department of Latino and Caribbean Studies, Program in Criminal Justice, Rutgers, The State University of New Jersey, Piscataway, NJ, USA 
not more agitated, more concerned, more upset about the machinations of neoliberalism that increasingly govern our lives.

The collaborative translations are, in part, intended to showcase that neoliberalism sucks for variously situated people around the world. The translations provide a written testament to the international nature of resistance to neoliberalism. In channeling another frustration that this text helps to relieve, I will reciprocate the polemic energy and share that I detest e-books, their price schemes, and their metastasizing presence. You cannot lend an e-book for free. You can purchase an e-book about climate change, but you need your electricitypowered device to access it. You cannot throw an e-book across a room or put it in a stack of books on your shelf. E-books cannot be placed strategically in the background of your zoom calls. And if you had this book in digital form on your bullshit Amazon Kindle, it would be a subtle neoliberal parody of itself. Having physical copies of things matters. When the authoritarian regime shuts down your internet access, or when another extreme weather event knocks out your energy infrastructure, or when you find yourself waiting in line for hours to fulfill a basic human need, or when the state police seize your tablet at the airport because you were reading Noam Chomsky or the theory of evolution again, you will appreciate that this book is available in physical form. Whether at the hipster café or the private detention facility near you, this book was made to be shared.

My only critique of the text is that it devotes too much attention to their internal decision to use the term "fuck." In short, the author seems to imply that it is a rather bold decision to use such a word in the title of one's publication, when it is actually quite common (see the arbitrarily derived "Fuck Index" below). As I was reading this section, my millennial brain could only think: "Go off, king—say whatever tf you want! It's your book!"

The political ethos of the text is not only admirable, but a necessary contribution to the academic and popular record. When we (or others) look back and examine what we did through our day jobs, I believe this book will age well. It will show that even academics (who are rather risk-averse and part of a structurally conservative enterprise) could not ignore the fundamentally dystopian trajectory that many of us feel we are on, and the twenty-one languages and the perspectives of the translators underscore that we are connected in this experience. The language is not offensive, but necessary, and the energy captured in this book supports directly the continued coalition building to unfuck ourselves from the interests, incentives, and insidious state-corporate forces that seek to normalize this neoliberal existence while calling it "progress." Fuck neoliberalism, indeed.

\section{The Fuck Index*}

This is a list of articles based on a search of the word "fuck" through my university library's online search bar, filtered to include only "peer-reviewed journals." This is a convenience sample and in no way representative of all the compelling titles that one might find in a separate search.

Abdeldaim, Guma M. K., Kristoffer Strålin, Per Olcén, Jonas Blomberg, Paula Mölling, and Björn Herrmann. (2013). Quantitative FucK Gene Polymerase Chain Reaction on Sputum and Nasopharyngeal Secretions to Detect Haemophilus Influenzae Pneumonia. Diagnostic Microbiology and Infectious Disease, 76(2), 141-46. https://doi.org/10. 1016/j.diagmicrobio.2013.02.015. 
Amrute, Sareeta. (2016). Go the Fuck to Sleep: Well-Being, Welfare, and the Ends of Capitalism in US Discourses on Infant Sleep. South Atlantic Quarterly, 115(1), 125-48. https://doi.org/10.1215/00382876-3424786.

Bramwell, Richard, and James Butterworth. (2019). 'I Feel English as Fuck': Translocality and the Performance of Alternative Identities through Rap. Ethnic and Racial Studies, 42(14), 2510-27. https://doi.org/10.1080/01419870.2019.1623411.

Cucurella, Paula. (2020). 'Fuck Shakespeare' and MEChA in the '80s: An Interview with Daniel Chacón. Latino Studies, 18(1), 122-28. https://doi.org/10.1057/s41276019-00232-9.

Dahl, Ulrika. (2014). Not Gay as in Happy, but Queer as in Fuck You. Lambda Nordica, 19(3-4), 143-68. Retrieved on April 24, 2021, from https://www.lambdanord ica.org/index.php/lambdanordica/article/view/430/409.

de Jesús, Melinda Luisa. (2020). Three Meditations on Anti-Asian Violence and COVID-19, or Fuck Off, Andrew Yang! Journal of Asian American Studies, 23(3), 323-28. https://doi.org/10.1353/jaas.2020.0025.

DeGroot, Jocelyn M., and Heather J. Carmack. (2020). Unexpected Negative Participant Responses and Researcher Safety: 'Fuck Your Survey and Your Safe Space, Trigger Warning Bullshit.' Journal of Communication Inquiry, 44(4), 354-75. https://doi.org/10.1177/0196859920921752.

Diaz-Fernandez, Silvia, and Adrienne Evans. (2019). 'Fuck Off to the Tampon Bible': Misrecognition and Researcher Intimacy in an Online Mapping of 'Lad Culture.' Qualitative Inquiry, 25(3), 237-47. https://doi.org/10.1177/1077800418 800757.

Fairman, Christopher M. (2006). Fuck. Cardozo Law Review, 28(4), 1711-72. HeinOnline, https://heinonline-org.proxy.libraries.rutgers.edu/HOL/P?h=hein.journ als/cdozo28\&i $=1727$.

Gerrard, Jessica, and Jo Ball. (2013). From Fuck Marry Kill to Snog Marry Avoid?: Feminisms and the Excesses of Femininity. Feminist Review, 105(1), 122-29. https:// doi.org/10.1057/fr.2013.26.

Gough, Jamie. (2019). 'Fuck Business': The Conservative Party, Capital, and Britain's EU Membership. Human Geography, 12(3), 47-51. https://doi.org/10.1177/ 194277861901200307.

Healy, Kieran. (2017). Fuck Nuance. Sociological Theory, 35(2), 118-27. https://doi. org/10.1177/0735275117709046.

Henkes, Andrew J. (2013). A Party for the 'Freaks': Performance, Deviance and Communitas at Club Fuck!, 1989-1993. The Journal of American Culture, 36(4), 284-95. https://doi.org/10.1111/jacc.12050.

Hudson, Bryant Ashley. (2019). Fuck, Fuck, Fuck: Reflexivity and Fidelity in Reporting Swearwords in Management Research.M@n@gement, 22(3), 487-95. https:// management-aims.com/index.php/mgmt/article/view/3769.

Kay, Jilly Boyce. (2020). 'Stay the Fuck at Home!': Feminism, Family and the Private Home in a Time of Coronavirus. Feminist Media Studies, 20(6), 883-88. https:// doi.org/10.1080/14680777.2020.1765293. 
León, Kenneth Sebastián. (2021). Latino Criminology: Unfucking Colonial Frameworks in 'Latinos and Crime' Scholarship. Critical Criminology: An International Journal, 29(1), 11-35. https://doi.org/10.1007/s10612-020-09544-y.

Leonard, David. (2009). Young, Black (\& Brown) and Don't Give a Fuck: Virtual Gangstas in the Era of State Violence. Cultural Studies $\leftrightarrow$ Critical Methodologies, 9(2), 248-72. https://doi.org/10.1177/1532708608325938.

Lohmeyer, Ben Arnold. (2020). 'Keen as Fuck': Youth Participation in Qualitative Research as 'Parallel Projects.' Qualitative Research, 20(1), 39-55. https://doi.org/10. $1177 / 1468794118816627$.

Nicholson, Mervyn. (2013). Fuck Austerity. English Studies in Canada, 39(4), 25-29. Retrived on March 30, 2021, from https://ojs.lib.uwo.ca/index.php/esc/article/view/ 9614/7714.

Nilsson, Per-Erik. (2019). Fuck Autonomy: Neo-Orientalism and Abjection in Michel Houellebecq's Soumission. European Review, 27(4), 600-614. https://doi.org/10.1017/ S1062798719000206.

Peterson, David A. M. (2020). "Dear Reviewer 2: Go F' Yourself." Social Science Quarterly. https://doi.org/10.1111/ssqu.12824.

Rúdólfsdóttir, Annadís G., and Ásta Jóhannsdóttir. (2018). Fuck Patriarchy! An Analysis of Digital Mainstream Media Discussion of the \#freethenipple Activities in Iceland in March 2015. Feminism \& Psychology, 28(1), 133-51. https://doi.org/10.1177/09593 53517715876.

Santos, Ana Cristina, and Ana Lúcia Santos. (2018). Yes, We Fuck! Challenging the Misfit Sexual Body through Disabled Women's Narratives. Sexualities, 21(3), 303-18. https://doi.org/10.1177/1363460716688680.

Smith, Jade, and Ralph Adendorff. (2021). Reading Parents: Parody and Paradox in Go the Fuck to Sleep. Language \& Communication, 77(March), 81-92. https://doi.org/10. 1016/j.langcom.2020.12.004.

Weerawardhana, Chamindra. (2018). 'What Is It about "Fuck off” You Don't Understand?' The NILRC and Politics of the Left in Northern Ireland. Labor History, 59(5), 593-609. https://doi.org/10.1080/0023656X.2018.1467300.

Wood, Helen. (2019). Fuck the Patriarchy: Towards an Intersectional Politics of Irreverent Rage. Feminist Media Studies, 19(4), 609-15. https://doi.org/10.1080/14680777. 2019.1609232.

Wood, Mark A. (2018). 'I Just Wanna See Someone Get Knocked the Fuck out': Spectating Affray on Facebook Fight Pages. Crime Media Culture, 14(1), 23-40. https://doi. org/10.1177/1741659016667437.

Publisher's Note Springer Nature remains neutral with regard to jurisdictional claims in published maps and institutional affiliations. 